\author{
Dorota Guttfeld \\ Uniwersytet Mikołaja Kopernika w Toruniu \\ gutt@umk.pl
}

\title{
DYLEMATY W DYDAKTYCE PRZEKŁADU LITERACKIEGO
}

DOI: http://dx.doi.org/10.12775/RP.2016.009

\begin{abstract}
Zarys treści: Dydaktyka przekładu literackiego wymaga od prowadzących wyjątkowo autorskiego podejścia do przygotowania zajęć, tak ze względu na twórczą naturę przekładu literackiego, jak i niedostatek dostępnych podręczników. Artykuł omawia niektóre zagadnienia wymagające przemyślenia w trakcie projektowania takiego kursu w ramach studiów filologicznych: od roli, jaką ma spełniać w programie nauczania, przez dobór źródeł i materiałów do przekładu, po typy zadań i kryteria oceny.
\end{abstract}

Słowa kluczowe: przekład literacki, dydaktyka przekładu

\section{Przekład literacki w programie specjalizacji tłumaczeniowej}

ak zauważa Krzysztof Fordoński w artykule Rynek przekładu literackiego w Polsce po roku 2000, „[j]edynie niewielka część absolwentów filologii obcych zajmie się kiedykolwiek przekładami literackimi” (2012: 95), a „[o]ferowane na polskich uczelniach specjalizacje tłumaczeniowe w ramach studiów filologicznych skupiają się na opcjach uznawanych za bardziej komercyjne - przekładzie specjalistycznym i konferencyjnym” (2012: 96). Ocenę tę potwierdza przegląd programów nauczania na studiach II stopnia z zakresu anglistyki i językoznawstwa stosowanego oferowanych przez wiodące polskie uczelnie (UW, UJ, UAM, UWr, UG), gdzie w ramach specjalności przekładoznawczych stałe i obowiązkowe przedmioty poświęcone przekładowi literackiemu (np. proza w przekładzie, tłumaczenie tekstów literackich, tłumaczenie literackie) pojawiają się najczęściej na przestrzeni jednego semestru, 
w zakresie 30 godzin kontaktowych. Taki jest też przypadek specjalności tłumaczeniowej oferowanej przez Katedrę Filologii Angielskiej UMK w Toruniu: wśród zajęć dominują kursy poświęcone typom przekładu, których kandydaci i absolwenci prawdopodobnie będą potrzebować na rynku pracy, a więc podstawom tłumaczeń prawniczych, ekonomicznych, specjalistycznych, naukowych i audiowizualnych oraz przekładowi ustnemu. Fakt, że niewielu absolwentów znajduje zatrudnienie jako pełnowymiarowi tłumacze literatury, nie oznacza jednak, że nie jest to częsta ambicja ani że przekład literacki jest zupełnie nieobecny w programach studiów, zwłaszcza podyplomowych (na przykład w Katedrze UNESCO Uniwersytetu Jagiellońskiego). Jednak również w ramach studiów filologicznych, nawet jako przedmiot do wyboru, w niewielkim wymiarze godzinowym lub z niewielką liczbą punktów ECTS, może pełnić istotną funkcję w programach nauczania.

Po pierwsze, mimo stosunkowo słabych perspektyw komercyjnych na kurczącym się rynku (Fordoński 2012: 95) przekład literacki to jedna z naturalnych nisz zawodowych dla filologów. Fordoński wypowiada się dość sceptycznie o przydatności dla debiutanta kursów i warsztatów przekładu literackiego oferowanych $\mathrm{w}$ formie podyplomowej czy weekendowej; dobrze, aby kandydaci na tłumaczy dostawali już na etapie studiów możliwość zweryfikowania swoich ambicji i predyspozycji związanych z przekładem literackim lub - w bardziej optymistycznej wersji - zestaw przynajmniej podstawowych wskazówek i narzędzi, które mogą im umożliwić dalszy rozwój tego typu umiejętności.

Po drugie, brak takiego przedmiotu lub jego przesunięcie do puli nieobowiązkowej, w sytuacji gdy obowiązkowo naucza się przekładu tekstów specjalistycznych, tworzyłby mylne wrażenie, że do przekładu literackiego nie trzeba żadnych specyficznych umiejętności lub przeciwnie - że można go uprawiać wyłączne dzięki wrodzonym talentom, cechom osobowościowym czy ulotnemu natchnieniu, których nie ma sensu ćwiczyć i nie wypada oceniać.

Po trzecie, oprócz bycia celem samym w sobie nauczanie przekładu literackiego na późniejszych etapach studiów może odgrywać bardzo ważną rolę w integracji, uzupełnianiu i rozwijaniu kompetencji studentów: umiejętności językowych, praktycznych umiejętności tłumaczeniowych, a także umiejętności badawczych i poszerzaniu wiadomości teoretycznych związanych z przekładoznawstwem oraz innymi blokami treści filologicznych.

$\mathrm{Z}$ punktu widzenia praktycznej nauki języka angielskiego praca nad analizą i przekładem tekstów literackich może oznaczać kontakt z rzadziej używanymi leksemami i strukturami, których inaczej student może nie na- 
potkać albo mógłby unikać. Jak przekonująco ilustruje Clifford E. Landers, przekład literacki obnaża wszelkie pomyłki i wątpliwości co do poszczególnych terminów i struktur, ich konotacji - regionalnej, klasowej, potocznej, wulgarnej, specjalistycznej, humorystycznej (Landers 2001: 72-74), a także ich etymologii (118-122), stopnia poprawności i częstotliwości stosowania (132-137). Całe kategorie problemów, na przykład zastosowanie inwersji czy rzadziej używanych czasów, ujawniają się w kontrastywnym kontekście przekładu, a zwłaszcza przekładu tekstów literackich, które nie ciążą w stronę plain English czy reguł języka akademickiego.

Nauczanie przekładu literackiego pozwala na zastosowanie w praktyce różnorodnych wiadomości z zakresu językoznawstwa. Tak jak w przekładzie na potrzeby dubbingu wdraża się wiadomości zdobyte na zajęciach $\mathrm{z}$ fonetyki, tak w przekładzie literackim można wykorzystać wiedzę o ikoniczności składni, słowotwórstwie (przekład neologizmów), polach semantycznych i prototypowości (przekład elementów nacechowanych kulturowo) czy odmianach angielszczyzny (przekład dialogów w niestandardowym dialekcie). W dydaktyce przekładu literackiego przydatne okazują się również terminy z zakresu literaturoznawstwa: teorii literatury (interpretacja tekstu źródłowego), a zwłaszcza poetyki i stylistyki (analiza środków użytych w tekście oryginalnym). Te dziedziny i pojęcia, często postrzegane przez studentów jako czysto akademickie, otrzymują tu szansę na udowodnienie swej przydatności, na przykład kiedy psychoanalityczne, postkolonialne czy feministyczne odczytanie danego fragmentu skutkuje wyborem konkretnego tłumaczenia danej frazy albo przekład wiersza wymaga odświeżenia wiadomości z wersologii.

Wreszcie, przekład literacki to poligon, na którym studenci mogą doskonalić kompetencje związane z przekładem i wiedzę przekładoznawczą. Jak wykazują liczne prace $\mathrm{z}$ pogranicza kognitywistyki, efekty zazwyczaj kojarzone z tekstami literackimi pojawiają się również w tekstach nieliterackich i specjalistycznych, których przekład omawiany jest zwykle na oddzielnych zajęciach, gdzie jednak może brakować czasu na głębszą analizę tego aspektu. Funkcjonalistycznie przekład literacki to ćwiczenie tłumaczenia tekstów o dominującej funkcji ekspresyjnej, obecnej także w innych tekstach: reklamowych, gdzie występują nierzadko chwyty typowe dla poezji, turystycznych, publicystycznych, popularnonaukowych czy - by trzymać się terminologii Reiss (1989) - audiomedialnych. O ile zajęcia poświęcone przekładowi audiowizualnemu omawiają $\mathrm{w}$ dużej mierze specyficzne uwarunkowania techniczne i proces tworzenia takich tłumaczeń, problemy takie jak wiarygodny przekład dialogów stanowią punkt styczny z przekładem literackim. 
Przekład literacki pozwala też na przypomnienie rozmaitych koncepcji przekładoznawczych, zwłaszcza kategorii możliwych zachowań tłumacza wobec danego problemu, dzięki którym studenci mogą zaproponować wachlarz potencjalnych rozwiązań i spośród nich, zgodnie z postulatem Pyma, wybrać konkretne tłumaczenie (Pym 2003).

Kurs taki jest też niezwykle istotny dla studentów przekładoznawstwa piszących prace dyplomowe. Przekład literacki, a zwłaszcza tłumaczenie prozy fabularnej, poezji i dramatu, to dziedziny popularne wśród studentów. Spośród wszystkich poświęconych przekładoznawstwu prac dyplomowych promowanych przez kadrę Pracowni Przekładoznawstwa KFA od chwili utworzenia specjalizacji tłumaczeniowej II stopnia ponad $46 \%$ stanowią prace poświęcone przekładowi prozy fabularnej i poezji, a i w pozostałych tematach dominują zagadnienia pokrewne tłumaczeniom literackim: problematyka dialektów, gier słownych, metafor, nawiązań intertekstualnych czy elementów kulturowych w przekładzie filmów, komiksu, piosenek, gier komputerowych, skeczy, literatury faktu czy religijnej. Zainteresowaniu temu sprzyja bogactwo materiału do analizy, jaką oferuje choćby pojedyncza powieść czy tomik wierszy, w odróżnieniu do pojedynczej umowy, broszury czy nawet typowego filmu; przy tym jest to materiał łatwo osiągalny (w przeciwieństwie na przykład do tekstów tłumaczeń prawniczych), a równoległa lektura powieści i jej przekładu zwykle ujawnia jakiś nieoczekiwany aspekt czy obszar trudności, który może stanowić punkt wyjścia do badań. Nadto teksty literackie, zwłaszcza klasyczne, cieszą się prestiżem, który sprawia, że zwykle nie trzeba się tłumaczyć z ich wyboru jako tematu pracy. Do priorytetowego traktowania literatury pięknej studenci są wdrażani w trakcie całego toku studiów, obfitującego (choć może mniej niż niegdyś) w zajęcia literaturoznawcze, co koreluje też z profilem kandydatów, a zapewne również osobistymi zainteresowaniami studentów. Zgodnie z postulatem, by w pracy dyplomowej zajmować się tym, co autora naprawdę interesuje i sprawia mu przyjemność (Dybiec-Gajer, Piotrowska 2012: 17), oprócz klasyki studenci wybierają do analizy sezonowe bestsellery, cieszącą się dużą popularnością fantastykę czy darzoną sentymentem literaturę dziecięcą i młodzieżową. Już choćby dlatego studenci, którzy chcą zmierzyć się z krytyką lub analizą przekładu literackiego, powinni sami spróbować sił jako tłumacze tekstów literackich lub przynajmniej ich fragmentów.

Choć przekład literacki może odegrać ważną rolę w programie nauczania, projektowanie takiego kursu $\mathrm{w}$ ramach studiów filologicznych wymaga bardzo autorskiego podejścia i odpowiedzi na wiele pytań - po pierwsze, ze względu na samą naturę przedmiotu, gdzie trudno o jednoznaczne przykła- 
dy „tekstu literackiego” czy kryteria jego „dobrego przekładu”; po drugie, ze względu na niedostatek podręczników uniwersyteckich omawiających podstawy przekładu literackiego w kontekście tłumaczeń angielsko-polskich. Jak konstatuje Aleksandra Kowalewska w Problematyce przekładu stylu literackiego, liczba prac omawiających poszczególne przekłady nie przełożyła się dotąd na obfitość całościowych ujęć przekładu literackiego w ramach przekładoznawstwa, „nie określono też dokładnie skutecznych metod analizy stylistycznej ani nie opisano w wyczerpujący sposób faz procesu przekładu artystycznego" (2005: 167). Poniższa część artykułu omówi kilka najważniejszych pytań stających przed prowadzącymi zajęcia z przekładu literackiego w ramach studiów filologicznych na poziomie magisterskim co do treści kursu, doboru źródeł i materiałów do przekładu, typów ćwiczeń i metod oceny przekładów.

\section{Treści kursu}

Uznajmy za Fordońskim, że sensem zajęć z przekładu literackiego w ramach studiów filologicznych nie jest uczynienie ze studentów profesjonalnych tłumaczy literackich, ponieważ ani pozycja przedmiotu w programach nauczania, ani rzeczywistość rynkowa nie dają na to wielkich nadziei, nawet jeżeli umiejętności najlepszych studentów stwarzałyby po temu możliwości. Celem będzie więc przekazanie pewnego minimum wiadomości i umiejętności związanych ze wszystkimi etapami przekładu: dekodowaniem tekstu źródłowego, w tym identyfikacją cech stylistycznych tekstu i jego „punktów krytycznych" w świetle możliwych interpretacji; wyborem strategii i technik tłumaczenia; produkcją, krytyczną lekturą i poprawianiem tekstu w języku docelowym. Jeżeli pojęcia przekładoznawcze lub literaturoznawcze mogą pomóc na którymś z etapów pracy, warto postarać się, by kurs przekładu literackiego zazębiał się z takimi zajęciami, ale nie można go sprowadzać do roli ćwiczeń z przekładoznawstwa czy literaturoznawstwa. Powinien też uzupełniać się $\mathrm{z}$ innymi zajęciami praktycznymi z tłumaczeń: o ile etapy pracy wyglądają podobnie w przypadku przekładów literackiego i specjalistycznego, niektóre nawyki, przydatne też w innych zadaniach tłumaczeniowych, łatwiej wyćwiczyć właśnie w ramach przekładu literackiego. Należą do nich na przykład:

- zdolność radzenia sobie ze służebną rolą tłumacza. Początkujący często utożsamiają tłumaczenie literackie z przekładem dowolnym, byle odpowiednio „udziwnionym”, i w nieuzasadniony sposób ingerują 
w styl utworu lub zaniedbują podstawowy sens wypowiedzi autora, weryfikację faktograficzną realistycznych elementów tekstu literackiego czy poszukiwanie odpowiedniej terminologii;

- umiejętność dostrzegania pułapek językowych i niejednoznaczności w tekście oryginalnym, co wymaga krytycyzmu w stosunku do pierwszego dokonanego przez siebie rozbioru zdania czy początkowej interpretacji akapitu. Umiejętność ta bazuje na gotowości do wnikliwej i wielokrotnej lektury tekstu;

- umiejętność kompensowania utraty pewnych wartości w innym miejscu tekstu lub za pomocą innych środków, na przykład w celu zachowania humoru. Wymaga ona zdolności do radzenia sobie z elementami uważanymi za nieprzekładalne, zamiast zamykania na nie oczu, poddawania się rezygnacji albo bezowocnej frustracji;

- wrażliwość na rejestr i stylizację (sztuczną lub na język rzeczywisty, $\mathrm{w}$ tym mówiony) oraz zmiany stylistyczne w przekładzie (jak uszlachetnienie lub upotocznienie języka, zastosowanie leksyki bardziej abstrakcyjnej lub konkretnej, zmiana długości i konstrukcji zdań, eliminacja efektów brzmieniowych) i potencjalne znaczenie takich zmian dla wartości i wymowy tekstu.

\section{Dobór źródeł}

Na polskim rynku brak podręcznika akademickiego do nauki podstaw przekładu literackiego, wobec czego prowadzący, jeśli chce się oprzeć na czymś więcej niż własny autorytet i doświadczenie, zapewne spróbuje korzystać z wielu rozproszonych źródeł. Opracowanie bibliografii dostępnych materiałów wykracza poza ramy niniejszego artykułu, poprzestanę więc na zaproponowaniu kryteriów doboru materiałów i wskazaniu przykładów w każdej z kategorii. Można tu wyodrębnić publikacje omawiające poprawnościowe i stylistyczne aspekty języka źródłowego i docelowego, aspekty przekładoznawcze typowe dla tłumaczenia literackiego i aspekty praktyczne procesu przekładu.

W tej pierwszej grupie wiele publikacji będzie się oczywiście powtarzać $\mathrm{z}$ literaturą wykorzystywaną $\mathrm{w}$ innych kursach przekładu. Problemy związane z niewolniczym kopiowaniem struktury zdań oryginału omawia Poradnik tłumacza Belczyka. Rozumieniu i przekładowi zaawansowanych struktur gramatycznych ma być poświęcony podręcznik $A$ Handbook of Techinques for Polish-English Translation, którego wydanie zapowiada Daniel Sax. W spra- 
wach poprawnościowych warto zachęcić studentów do korzystania nie tylko z zasobów online (Słownik ortograficzny PWN), ale też publikacji książkowych (np. Jak się mówi...? Jak się pisze...? pod red. Czerwińskiej, Podrackiego i Wendołowskiej czy Formy i normy pod red. Kłosińskiej). Zagadnienie interpunkcji w dialogach, często stanowiące duży problem dla studentów, przejrzyście omawia poradnik Wolańskiego Edycja tekstów. Powtórkę wiadomości z polskiej stylistyki i poetyki ułatwić mogą zadania oparte na klasycznej serii Wiersz. Podstawowe kategorie opisu pod red. Woronczaka czy przystępniejsze dla studentów Ćwiczenia ze stylistyki pod red. Zdunkiewicz-Jedynak i Ćwiczenia z poetyki pod red. Gajewskiej, Mizerkiewicza i Balcerzana. Jeżeli wiedzy tej nie przekazuje osobny kurs poświęcony kulturze języka polskiego czy polszczyźnie dla tłumaczy, wiele źródeł z tej grupy można zadać jako lektury do samodzielnych ćwiczeń w domu ze względu na przyjazną dla studentów strukturę (na przykład obszerne klucze do ćwiczeń w Formach i normach czy Ćwiczeniach z poetyki). Jeśli chodzi o interpretację, to Przekład literacki jako metafora Kozak ilustruje zastosowanie metody kodów semicznych na potrzeby przekładu. Dla studentów cenne są też wszelkie publikacje zawierające konkretne wskazówki i listy pytań przypominające o potencjalnie ważnych cechach tekstu źródłowego. Przydatny pod tym względem jest klasyczny podręcznik Leecha Style in Fiction, z jego podrozdziałem A checklist of linguistic and stylistic categories, i Linguistic Guide to English Poetry. Zwięzłą listę pytań, jakie powinien zadać sobie i wierszowi tłumacz, zawiera From World to World Ceesa Kostera.

Druga kategoria źródeł to artykuły i opracowania przekładoznawcze dotyczące problemów typowych dla przekładu literackiego (choć niekoniecznie tylko tam obecnych) i wybrane pozycje z teorii przekładu. Z obfitej literatury wskazany wydaje się dobór raczej krótszych i mniej teoretycznych tekstów bogato ilustrowanych przykładami, a także takich, które prezentują opisowe kategoryzacje możliwych zachowań tłumaczy, bo dzięki nim studenci mogą poznać spektrum możliwości: umiejętność nazwania różnych opcji przekładu pozwala studentom łatwiej przypomnieć sobie o możliwości ich zastosowania, a prowadzącemu - łatwiej udzielać wskazówek bez podawania konkretnych rozwiązań. Takich wskazówek dotyczących możliwych zachowań tłumacza dostarczają na przykład wycinkowe studia nad konkretnymi problemami: przekładem elementów kulturowych (np. Culture-specific items in translation Aixeli czy Obcość w odbiorze przekładu Lewickiego), dialektu (np. Dialect in Translation Berezowskiego czy rozdział Translating polyphonic texts $\mathrm{z}$ Translation. A Cognitive-Communicative Approach Hejwowskiego), metafor (np. rozdział The Translation of Metaphors z A Textbook of Translation New- 
marka) czy choćby zastosowania przypisów (artykuł Kizeweter Przepis na przypis w zbiorze Jakość i ocena tłumaczenia). Na podobnej zasadzie jak kategoryzacje technik przekładu szczególnie wartościowe wydają się też wszelkie kategoryzacje błędów, np. lista typów błędów z Komunikacyjno-kognitywnej teorii przekładu Hejwowskiego czy tendencji tłumaczeniowych deformujących tekst literacki opisane przez Bermana w Przekładzie jako doświadczeniu obcego (niektóre wymienione przez Bermana tendencje omawia w odniesieniu do praktyki przekładu angielsko-polskiego Jarniewicz w esejach zebranych w tomie Gościnność słowa). Wreszcie refleksję nad własnym tłumaczeniem ułatwia studentom znajomość przynajmniej podstawowych terminów z teorii przekładu: pojęć kompensacji, dominanty semantycznej, kontrowersji wokół przekładu udomawiającego i wyobcowującego czy spostrzeżeń Toury'ego na temat standaryzacji i interferencji w przekładzie. Ze źródeł tego typu warto korzystać w miarę pojawiania się konkretnych problemów przekładowych, być może we fragmentach, by studenci mieli poczucie, że nie obcują $\mathrm{z}$ teorią dla niej samej, ale podejmują decyzje, korzystając z porad teoretyków.

Trzecią i chyba najciekawszą dla studentów grupę lektur stanowią praktyczne uwagi i autokomentarze tłumaczy literatury, pozwalające zajrzeć do warsztatu tłumacza zmagającego się z kolejnymi wersjami tekstu docelowego, takie jak refleksje Juliana Tuwima w Czterowierszu na warsztacie, przy czym oczywiście dla studentów anglistyki najcenniejsze są przykłady tłumaczeń $\mathrm{z}$ angielskiego. Klasyczną i ważną pozycją jest na pewno Ocalone w tłumaczeniu Stanisława Barańczaka, szczególnie przydatne, jeżeli trzeba wyrobić w studentach wrażliwość na formę wiersza czy uleczyć z niewolniczego trzymania się litery oryginału kosztem jego znaczenia, a antologia problemów tłumaczeniowych zawarta na końcu książki to właściwie gotowe ćwiczenia z przekładu poetyckiego. Poradnik Literary Translation: A Practical Guide Clifforda Landersa cytuje niestety przykłady tłumaczeń na angielski z języków romańskich, ale dobór problemów jest bardzo uniwersalny, styl lekki, a porady życiowe, choć charakteryzuje je duża skrótowość (na przykład trzy strony o problemie stylu) i niekiedy duży stopień ogólności. Co prawda O przekładzie na przykładzie i Tłumaczac się $z$ tłumaczenia Elżbiety Tabakowskiej opisują proces przekładu tekstu popularnonaukowego, ale można tu znaleźć sporo informacji interesujących tłumacza literatury pięknej: opis współpracy z korektą i redakcją, przykłady poszukiwań terminologicznych, problemy przekładu metafor, gier słownych, aliteracji, elementów kulturowych, a podrozdział Gramatyka a perspektywa, będący w istocie popularną ilustracją tez językoznawstwa kognitywnego, zwraca uwagę studentów na konieczność wnikliwej analizy tekstu. Publikacje z tej kategorii świetnie 
sprawdzają się jako lektury dodatkowe, $\mathrm{z}$ otwartej listy do wyboru studenta. Punkt wyjścia do ćwiczeń i dyskusji mogą stanowić też dwujęzyczne wydania przekładów, na przykład z serii Wydawnictwa Literackiego czy Biblioteki Poetów Języka Angielskiego, a także eseje pisarzy odsłaniające tajniki kuchni literackiej; można na przykład wyobrazić sobie kształcącą analizę polskich przekładów „Kruka” równolegle z lekturą „The Philosophy of Composition”.

\section{4. Ćwiczenia związane z przekładem i podejście do ewaluacji}

Oprócz samego tłumaczenia, w ramach kursu przekładu literackiego studenci mogą wykonywać zadania niezwiązane bezpośrednio z przekładem (na przykład ćwiczenia czysto językowe, dotyczące interpunkcji czy szyku zdania, na rzeczywistych czy spreparowanych tekstach), a także różne zadania cząstkowe (na przykład przygotowywać terminologię, identyfikować i omawiać „punkty krytyczne" oryginału). Mogą też pracować na istniejących już przekładach, własnych (motywując i oceniając swoje wybory) albo cudzych, na przykład recenzując nawzajem tłumaczenia studenckie lub analizując istniejące przekłady profesjonalne. Pierwszy dylemat prowadzącego dotyczy roli tych zadań i proporcji między nimi a samym przekładem. Zadania cząstkowe skupione na wstępnych fazach tłumaczenia sprawdzają się na początkowym etapie nauki, zanim jeszcze studenci zaczną wykonywać pełne przekłady, lub jako część pracy $\mathrm{w}$ tandemie, gdzie na przykład jedna osoba przygotowuje terminologię i proponuje strategię wobec punktów krytycznych, a druga na tej podstawie wykonuje przekład, dbając o poprawność, styl i formę tekstu. Praca w zespole pozawala zmniejszyć presję, a burze mózgów - zauważyć wiele aspektów tekstu, które pojedynczy student może przeoczyć (na przykład wieloznaczność jakiegoś terminu czy jego wagę dla potencjalnej interpretacji tekstu); jednak w większej dawce zadania takie mogą stać się frustrujące i monotonne.

Podobnie konfrontowanie swoich wczesnych pomysłów z gotowym przekładem profesjonalnym, choć bardzo pouczające, na dłuższą metę albo onieśmiela początkujących tłumaczy (jeżeli są to przekłady godne naśladowania), albo grawituje w stronę tropienia błędów (jeśli dobieramy przekłady $\mathrm{z}$ usterkami). Wyłapywanie pomyłek czy niedociągnięć w tłumaczeniach profesjonalnych wdraża studenta do uważnej lektury tekstu, służy jako przestroga i zarazem podbudowuje morale, jednak w dłuższej perspektywie nie jest korzystne z punktu widzenia umiejętności krytyki przekładu, jak to przekonująco opisuje Brzozowski w pracy Stanać po stronie tłumacza. Zarys poetyki opisowej przekładu (2011). Warto więc zadbać, by studenci nie tylko wykry- 
wali błąd, ale też określali jego wagę, prawdopodobne przyczyny i możliwość dostrzeżenia go przez czytelnika, a także, jak postuluje Brzozowski, dostawali szansę analizy przekładów udanych (2011: 8).

Można też konfrontować oceny studentów z ocenami czytelników i specjalistów, dobierając do analizy przekłady, które doczekały się szczegółowych i kompetentnych recenzji ( $w$ tym autorstwa innych tłumaczy), co niekiedy pozwala stonować zbyt pochopnie ferowane sądy. Co ciekawe, w pewnym sensie użyteczne okazują się też recenzje i opisy skrajnie niekompetentne. $\mathrm{Na}$ przykład aby wskazać konieczność odporności na krytykę i wyznaczenia dominanty w przekładzie, po zadaniu tłumaczeniowym wymagającym niezwykle mozolnej pracy terminologicznej studenci porównują swoje tłumaczenie z dobrze wykonanym przekładem profesjonalnym, by następnie przeczytać jego internetową recenzję, gdzie, niczym w parodii pióra Barańczaka (2004: 34), czytelnicy skupiają się na absolutnie nieistotnych detalach.

Bardziej wyważone oceny pojawiają się zwykle we wzajemnych recenzjach i korektach przekładów, czy to gotowych, czy dopiero tworzonych, na różnych etapach ich powstawania (propozycję pytań do samooceny i wzajemnej oceny studenckiej można znaleźć na przykład w Zmierzyć przekład? Dybiec-Gajer, 2013: 174). Niestety, takie zadanie częściej pokazuje deficyty w kompetencji językowej i tłumaczeniowej u studentów oceniających (co oczywiście też jest cenne), niż trafnie diagnozuje problemy w ocenianych tekstach. Ciekawie sprawdza się zakodowanie prac i wmieszanie pomiędzy nie profesjonalnych przekładów tego samego tekstu.

Aby nie popaść $\mathrm{w}$ manierę skupiania się na błędach, warto zachęcić do bardziej holistycznej oceny przekładu rodem $\mathrm{z}$ Ricoeura, w kategoriach wierności, straty i ocalenia (Ricoeur 2008: 33-37). Takie spojrzenie można wymusić, dzieląc studentów na grupy, w których jedna osoba ma za zadanie przedstawić stworzony przez siebie tekst w języku angielskim (np. próbę literacką, opis wydarzenia), najlepiej ważny dla siebie emocjonalnie, a pozostałe pełnią funkcję tłumacza i korektora/wydawcy, który ma za zadanie sprawić, by wyznaczona na czytelników inna grupa studentów (druga grupa zajęciowa, studenci specjalizacji literaturoznawczej lub po prostu druga połowa sali) na koniec „kupiła” właśnie ten tekst spośród propozycji oferowanych przez inne trzyosobowe ekipy. Autor i korektor/wydawca mogą przekazywać swoje zażalenia wobec kolejnych wersji tekstu przekładu i wnosić poprawki, komunikując się wyłącznie z tłumaczem, przy czym korektor/wydawca powinien zasięgać też zdania przyszłych czytelników (np. w sprawie ich preferencji literackich, znajomości realiów czy terminologii, typu poczucia humoru czy stosunku do wulgaryzmów). Na koniec odbywa się głosowanie nad „listą be- 
stsellerów", a tłumacze opowiadają o konfliktach interesów w grupie. Choć ćwiczenie to jest czasochłonne i wymagające, przygotowuje tłumaczy do walki o najważniejsze kwestie i do zawierania kompromisów w mniej istotnych sprawach, a pozostałych członków grupy uwrażliwia na presję, pod jaką znajduje się tłumacz.

Jeżeli od studentów wymaga się przemyślanych ocen, oceniając ich prace należy dowieść, że choć analiza błędów „stanowi bazę dydaktyczną w polskim przekładoznawstwie" (Piotrowska 2007: 50), prowadzący nie oczekuje użycia wyłącznie strategii bezpiecznych, a oprócz stosowania error-based marking czy error deduction method jest też gotowy nagradzać pozytywne aspekty przekładu. Ponieważ, jak pisze Dybiec-Gajer, „[w] działalności przekładowej [...] element kreatywności odgrywa bardzo istotną rolę, a właśnie takie cechy jak indywidualność, oryginalność i twórczość najtrudniej pogodzić z zasadami diagnostyki unormowanej” (2013: 29), powinna to być też choć częściowo ocena holistyczna, nie tylko analityczna. Jeśli połączyć te postulaty z modelem proponowanym przez Brzozowskiego (2011: 196-199), etapy oceny tłumaczenia studenckiego powinny wyglądać mniej więcej następująco: przekład jest najpierw traktowany samodzielnie, z perspektywy czytelnika, w sposób analityczny (pod kątem błędów języka docelowego, błędów logicznych i rzeczowych, problemów z formatowaniem, literówek), a następnie holistyczny, zgodnie z postulatami Barańczaka (jako dobry lub niedobry wiersz czy tekst prozatorski). Potem, znając tekst oryginalny, należy skupić się na podejściu do tekstu i strategii tłumacza - tutaj w skład oceny może wchodzić holistyczna ocena studenckiego komentarza do przekładu (Dybiec-Gajer 2013: 134-135). Dopiero na koniec przekład należy zestawić z oryginałem i ocenić analitycznie z punktu widzenia już nie czytelnika, a filologa. Mielibyśmy więc trzy etapy oceny: z perspektywy czytelnika, skupiającego się na języku i treści tekstu docelowego; z perspektywy tłumacza, zaglądającego przez ramię młodszemu koledze; i z perspektywy filologa, obrońcy ekwiwalencji.

Niestety, w praktyce, sprawdzając pod rząd wiele przekładów tego samego tekstu, trudno nie zauważać od razu zaburzeń ekwiwalencji, które byłyby niewidoczne dla zwykłego czytelnika. Można jednak na początku zaznaczać tylko ich istnienie (podczas gdy za widoczne błędy w tekście docelowym od razu odejmuje się punkty), a po lekturze przekładu poszukać uzasadnienia dla nich w komentarzu studenckim: jeśli takowe istnieje, rozwiązania te otrzymują punkty dodatnie lub przynajmniej nie są karane, ale jeśli student ich nie uzasadnia lub uzasadnienie jest sprzecznie z wykonaniem, zostają odnotowane jako błędy. Do tej oceny dochodzi następnie składnik holistyczny, za sam przekład i komentarz do niego. Ponieważ w rzeczywistości tłumacz 
rzadko ma okazję szczegółowo komentować swój przekład w paratekście, ze względów dydaktycznych wskazane byłoby zmniejszanie z czasem udziału oceny komentarza w ocenie końcowej, a zwiększanie udziału oceny typowo „czytelniczej” i typowo „filologicznej”, jakiej tłumacz może oczekiwać od publiczności i akademii.

\section{Dobór tekstów oryginalnych}

Głównym typem zadań zlecanych studentom w ramach kursu przekładu literackiego są oczywiście różnorodne przekłady tekstów dostarczanych przez prowadzącego lub wybieranych przez studentów z określonej przez niego puli albo kategorii - i tu sprawą najważniejszą staje się ich dobór. Poniżej zajmę się krótko czterema problemami: wykorzystaniem tekstów sztucznie stworzonych, tekstów poetyckich, tekstów znanych i uznanych oraz tekstów znanych prowadzącemu z perspektywy tłumacza.

Mimo oczywistych zalet tekstów autentycznych, tekstów dydaktycznych (tj. spreparowanych na potrzeby dydaktyki) też nie trzeba od razu wykluczać. $\mathrm{Na}$ etapie wprowadzania poszczególnych zagadnień prowadzący może przygotować krótkie fragmenty pod kątem pojawiających się wśród studentów problemów w przekładzie: kłopotliwych konstrukcji gramatycznych, kalk leksykalnych i strukturalnych czy zauważania gier słownych. Spreparowane teksty źródłowe pozwalają zaprezentować do przekładu kilka wersji jednego dialogu na różnych poziomach formalności czy czterowiersza o tej samej treści, ale różnym metrum. Przydatnym ćwiczeniem jest poprawianie błędów w specjalnie spreparowanych tekstach polskich, o ile nie są to błędy na poziomie słynnego „Miodzie, jestem domem”, a katalog rzeczywiście pojawiających się pomyłek frazeologicznych i gramatycznych, od których dodatkowo można odwrócić uwagę jakimś innym poleceniem (na przykład maskując tekst jako ćwiczenie z interpunkcji czy listę porad zawodowych dla początkujących tłumaczy), by dopiero po lekturze sprawdzić, na ile zostały zauważone. Jeśli jednak zajęcia nie mają upodobnić się do ćwiczeń z praktycznej nauki języka z wykorzystaniem grammar-translation method, gros tekstów powinny stanowić autentyczne teksty literackie.

Jeżeli program studiów nie pozwala na utworzenie odrębnego kursu przekładu poetyckiego, który wymaga innych umiejętności i kategorii opisu niż przekład prozy (patrz na przykład Przekład literacki a translatologia, Krysztofiak 1999), trzeba też podjąć decyzję, czy zawęzić tematykę kursu do jednej opcji, czy uwzględnić i prozę, i poezję. Z przekładem prozy studenci zetkną 
się z większym prawdopodobieństwem, a jego dydaktyka łatwiej zazębia się $\mathrm{z}$ treściami innych zajęć, podczas gdy przekład poezji wymaga przypomnienia lub wprowadzenia wielu pojęć wersologicznych. Jednak uwzględnienie poezji niesie ze sobą duże korzyści: typowy wiersz to utwór o wiele bardziej zwięzły i skondensowany niż utwór prozatorski, oferuje więc dużo wyzwań, a jednocześnie możliwy jest do przetłumaczenia w całości. Tymczasem próbując ze studentami tłumaczyć cały utwór prozatorski, prowadzący ryzykuje, że tekst zdąży się im znudzić, ponieważ jego przekład zajmie większość kursu (jeśli będzie się go tłumaczyć lub polerować przekład „w odcinkach”, skupiając się na różnych aspektach) albo okaże się zbyt czasochłonnym wyzwaniem jak na cokolwiek poza pracą zaliczeniową. Alternatywą jest korzystanie tylko z fragmentów tekstów, co jednak na dłuższą metę może wyrabiać niedobry nawyk traktowania tekstu oryginalnego powierzchownie i oczekiwania, że wszelkie istotne elementy szerszego kontekstu zostaną wyjaśnione przez prowadzącego. Tekst podany do tłumaczenia w całości pozwala na przekazanie studentowi całej odpowiedzialności za jego odczytanie i późniejszy przekład. Dlatego przynajmniej do zadań cząstkowych związanych $\mathrm{z}$ analizą i interpretacją tekstu oryginalnego warto dobrać także utwory poetyckie. O ile tłumacz musi zetknąć się z typowymi elementami tekstu prozatorskiego (opis otoczenia, opis przeżyć wewnętrznych, scena akcji, scena miłosna, dialog), wiele problemów, jak przekład humoru i gier słownych, stylizacja i rejestr języka, można z powodzeniem pokazać na przykładach poezji.

Kolejne pytanie dotyczy decyzji, czy dawane studentom teksty źródłowe powinny być przykładami literatury z najwyższej półki, czy raczej tekstami anonimowymi, typowymi dla gatunku. Dużym plusem wykorzystania utworów rozpoznawalnych pisarzy jest motywacja; studentów można zmobilizować perspektywą tłumaczenia noblisty lub autora, którego dzieła omawiali na studiach. W takim przypadku studenci mogą wykorzystać $\mathrm{w}$ tłumaczeniu znane sobie - lub łatwe do odnalezienia - analizy i interpretacje klasycznych utworów. Jeżeli są to dzieła powszechnie znane, przy okazji znikają do pewnego stopnia zagrożenia związane $\mathrm{z}$ tłumaczeniem jedynie ich fragmentów. Nie jest to jednak sytuacja najzdrowsza i najbardziej realistyczna. Zazwyczaj tłumacz nie może polegać na obfitej literaturze ani wcześniejszej znajomości danej pozycji; na przykład student zapewne wie, jak „powinien” brzmieć Hemingway, nawet jeżeli faktycznie nie dostrzega tych cech w tekście oryginalnym. Teksty bardziej anonimowe, nawet stosunkowo sztampowe, pozwalają rozwinąć w studencie większą samodzielność, a wcale nie muszą być pozbawione problemów stylistycznych czy terminologicznych; zresztą początkujący tłumacz najczęściej musi się skupiać nie na wysokich problemach 
przekładu artystycznego, a na produkowaniu nadającej się do czytania, sensownej i zbliżonej znaczeniowo do oryginału prozy. Efekt motywacji można zaś uzyskać, dobierając po prostu fragmenty ciekawe fabularnie czy pod jakimś względem formalnym.

$\mathrm{Z}$ rozpoznawalnością tekstów wiąże się problem istnienia wcześniejszych polskich przekładów. Najwybitniejsze czy najpopularniejsze dzieła klasyków anglojęzycznych zapewne doczekały się polskich tłumaczeń, często dostępnych na kliknięcie myszki. Konfrontowanie początkujących tłumaczy od razu z gotowym przekładem wysokiej jakości, z którym mieliby utworzyć „serię przekładową", wydaje się działać raczej demotywująco: odbiera niekiedy wiarę w możliwość dorównania profesjonaliście i poczucie sensu wykonywanej pracy (skoro dobre tłumaczenie już przecież istnieje). Natomiast jeżeli przekład ten zawiera choćby drobne potknięcia, wymaga odświeżenia albo sugeruje możliwość zupełnie odwrotnego podejścia do tekstu (na przykład udomowienia, a nie wyobcowania), może stanowić dobry punkt wyjścia do powstania alternatywnych wersji studenckich. W większości przypadków korzystniejsze jest jednak, żeby studenci nie sugerowali się, przynajmniej z początku, istniejącym już przekładem, a co najwyżej po dokonaniu przekładu mieli jakiś punkt odniesienia, warto więc zawczasu sprawdzić, na ile dany tekst łatwo odnaleźć w internecie. Można oczywiście, jeśli chcemy tłumaczyć fragmenty już przekładanych tekstów, początkowo utrudnić rozpoznanie ich pochodzenia: nie zdradzać tytułu ani nazwiska autora, usunąć rozpoznawalne nazwy własne, udostępnić tekst w postaci papierowej, nie elektronicznej, i rozpocząć przekład od razu na zajęciach; zarazem takie postawienie sprawy robi się nierealistyczne, a umiejętność i nawyk poszukiwania wszelkich pomocnych źródeł należy przecież w studentach rozwijać i pochwalać.

Pozornie idealnym wyjściem jest wykorzystanie tekstów literackich, które akurat tłumaczą lub tłumaczyli prowadzący zajęcia. Jako tłumacze mogą mieć dostęp do tekstów niszowych lub świeżych, nadal anonimowych dla polskiej publiczności, a jeśli rzecz nie została jeszcze wydana, studenci nie mogą sugerować się cudzym przekładem. Przy tym tłumacz ma tekst zbadany i przemyślany pod wszystkimi możliwymi względami, dysponuje unikalnym wglądem w proces przekładu, korekty i redakcji tekstu, być może otrzymał też informację zwrotną od autora albo krytyki. Jednak wobec nakładu pracy, jaki prowadzący włożył w tłumaczenie, problemem może się okazać zachowanie obiektywizmu i otwartości wobec rozwiązań studentów. Łatwiej pokonać te trudności, wybierając jakąś swoją dawniejszą próbę, tekst czy przekład mniej lubiany, niż któreś z najświeższych czy subiektywnie najważniejszych tłumaczeń. Wśród studentów - o ile wiedzą, że tworzą przekład konkuren- 
cyjny wobec wersji swojego wykładowcy - nawet w takim przypadku może powstać przekonanie, że muszą trafić $\mathrm{w}$ „klucz nauczycielski”, a ponieważ próbują odtworzyć tok rozumowania osoby, która ma nad nimi dużą przewagę (choćby czasu poświęconego na lekturę oryginału i jego przekład), że cokolwiek zrobią, zrobią źle. W rezultacie taki dobór tekstów może się okazać paraliżujący i dla prowadzącego, i dla studentów.

\section{Podsumowanie}

Choć zaledwie niewielki odsetek studentów może związać karierę z przekładem literackim, kurs taki odgrywa ważną rolę w integracji kompetencji zdobytych w toku studiów filologicznych. Ze względu na zwykle drugoplanową rolę w programie studiów, a zatem często niewielką liczbę godzin czy punktów ECTS, wymaga dużej uwagi w doborze celów kształcenia, ćwiczeń i materiałów. Mimo to warto rozważyć uwzględnienie: ćwiczeń i metod oceniania kształtujących umiejętność holistycznego spojrzenia na przekład i jego wyważonej oceny; poezji jako przedmiotu analizy; utworów o zróżnicowanych wartościach artystycznych, w tym utworów mało znanych i trudniejszych do rozpoznania przez studentów.

\section{Literatura}

Aixela, J.F., 1996, „Culture-specific Items in Translation”, [w:] Translation, Power, Subversion, R. Alvarez, M.C.A. Vidal (red.), Clevedon, s. 52-78.

Barańczak, S., 2004, Ocalone w tłumaczeniu, Kraków.

Belczyk, A., 2001, Poradnik tłumacza: $z$ angielskiego na nasze, Kraków.

Berezowski, L., 1997, Dialect in Translation, Wrocław.

Berman, A., 2007, „Przekład jako doświadczenie obcego”, tłum. U. Hrehorowicz, [w:] Współczesne teorie przekładu, P. Bukowski, M. Heydel (red.), Kraków, s. 249-264.

Brzozowski, J., 2011, Stanać po stronie tłumacza. Zarys poetyki opisowej przekładu, Kraków.

Ćwiczenia ze stylistyki, 2016, D. Zdunkiewicz-Jedynak (red.), Warszawa.

Ćwiczenia z poetyki, 2006, A. Gajewska, T. Mizerkiewicz, E. Balcerzan (red.), Warszawa.

Dybiec-Gajer, J., 2013, Zmierzyć przekład? Z metodologii oceniania $w$ dydaktyce przekładu pisemnego, Kraków. 
Dybiec-Gajer, J., Piotrowska, M., 2012, Verba volant, scripta manent. How to write and M.A. thesis in Translation Studies, Kraków.

Fordoński, K., 2012, „Rynek przekładu literackiego w Polsce po roku 2000”, [w:] Rola tłumacza i przekładu w epoce wielokulturowości i globalizacji, M. Ganczar, P. Wilczek (red.), Katowice, s. 83-105.

Formy i normy, czyli poprawna polszczyzna w praktyce, 2001, K. Kłosińska (red.), Warszawa.

Hejwowski, K., 2004, Kognitywno-komunikacyjna teoria przekładu, Warszawa.

Hejwowski, K., 2004, Translation: A Cognitive-Communicative Approach, Olecko.

Jak się mówi...? Jak się pisze...? Poradnik językowy dla dziennikarzy, 2007, E. Czerwińska, J. Podracki, D. Wendołowska (red.), Warszawa.

Jarniewicz, J., 2012, Gościnność słowa. Szkice o przekładzie literackim, Kraków. Kizeweter, M., 2009, „Przepis na przypis - o przypisach na podstawie wybranych przekładów anglojęzycznej literatury pięknej na język polski”, [w:] Jakość i ocena tłumaczenia, A. Kopczyński, M. Kizeweter (red.), Warszawa, s. 36-63.

Koster, C., 2000, From World to World. An Armamentarium For the Study of Poetic Discourse in Translation, Amsterdam.

Kowalewska, A., 2005, „Problematyka przekładu stylu literackiego”, [w:] Kulturowe i językowe źródła nieprzekładalności, K. Hejwowski (red.), Olecko, s. 167-177.

Kozak, J., 2009, Przekład literacki jako metafora: między logos a lexis, Warszawa.

Krysztofiak, M., 1999, Przekład literacki a translatologia, Poznań.

Krysztofiak, M., 1996, Przekład literacki we wspótczesnej translatoryce, Poznań.

Landers, C.E., 2001, Literary Translation. A Practical Guide, Clevedon.

Leech, G., 1974, A Linguistic Guide to English Poetry, London.

Leech, G., Short, M., 2007, Style in Fiction, Harlow.

Lewicki, R., 2000, Obcość w odbiorze przekładu, Lublin.

Newmark, P., 2005, A Textbook of Translation, Harlow.

Piotrowska, M., 2007, Proces decyzyjny tłumacza. Podstawy metodologii nauczania przekładu pisemnego, Kraków.

Pym, A., 2010, Exploring translation theories, London.

Pym, A., 2003, „Redefining Translation Competence in an Electronic Age. In Defence of a Minimalist Approach", [w:] Meta (4)48, http://www.erudit. org/revue/meta/2003/v/-n4/008533ar.html (dostęp: 10 lipca 2015). 
Reiss, K., 1989, „Text types, translation types and translation assessment”, [w:] Readings in Translation Theory, A. Chesterman (red.), Helsinki, s. $105-115$.

Ricoeur, P., 2008, „O tłumaczeniu”, [w:] O tłumaczeniu, P. Ricoeur, P. Torop (red.), tłum. T. Swoboda, S. Ulaszek, Gdańsk, s. 33-59.

Tabakowska, E., 1999, O przekładzie na przykładzie, Kraków.

Tabakowska, E., 2009, Tłumaczac się z tłumaczenia, Kraków.

Tuwim, J., 2006, „Czterowiersz na warsztacie”, [w:] idem, Pegaz dęba, Warszawa, s. 191-209.

Wiersz. Podstawowe kategorie opisu, 1963, J. Woronczak (red.), Wrocław. Wolański, A., 2008, Edycja tekstów, Warszawa.

\section{Dilemmas in teaching literary translation}

\section{Summary}

The paper lists issues that a university teacher faces while designing a course in literary translation for students of English. The subject requires a very individual approach, both due to its nature and to the lack of textbooks covering English-Polish literary translation. On the basis of experience with such a course offered to students of English taking an MA programme in translation studies, the author lists important issues, starting with the rationale for including such a course in the curriculum, the choice of reference sources, selection of source texts for translation activities (poetry or prose, excerpts or whole texts, recognizable classics or relatively anonymous authors, text which have or have not been already translated), the choice of other types of activities (source text analysis, translation criticism, error correction in translations and target language texts), and assessment methods (holistic or focused on specific problems, from the perspective of a reader or that of a language teacher).

Keywords: literary translation, teaching translation 